\title{
The Relationship Between E-learning During Coronavirus Pandemic and Job Burnout among Faculty Members in Public and Private Universities in Jordan
}

Shehadeh Mofleh Al-gharaibeh, Dalal M. Al-Zoubi, Haitham Ali Hijazi, Asaad Al-Sakarneh, Hamzeh Mohamed Alhawamdeh, Mohammad Abdel Mohsen Al-Afeef

To Link this Article: http://dx.doi.org/10.6007/IJARBSS/v11-i11/11354

DOI:10.6007/IJARBSS/v11-i11/11354

Received: 08 September 2021, Revised: 11 October 2021, Accepted: 27 October 2021

Published Online: 18 November 2021

In-Text Citation: (Al-gharaibeh et al., 2021)

To Cite this Article: Al-gharaibeh, S. M., Al-Zoubi, D. M., Hijazi, H. A., Al-Sakarneh, A., Alhawamdeh, H. M., \& AlAfeef, M. A. M. (2021). The Relationship Between E-learning During Coronavirus Pandemic and Job Burnout among Faculty Members in Public and Private Universities in Jordan. International Journal of Academic Research in Business and Social Sciences, 11(11), $1983-2011$.

\section{Copyright: (c) 2021 The Author(s)}

Published by Human Resource Management Academic Research Society (www.hrmars.com) This article is published under the Creative Commons Attribution (CC BY 4.0) license. Anyone may reproduce, distribute, translate and create derivative works of this article (for both commercial and non0-commercial purposes), subject to full attribution to the original publication and authors. The full terms of this license may be seen

at: http://creativecommons.org/licences/by/4.0/legalcode

Vol. 11, No. 11, 2021, Pg. $1983-2011$ 


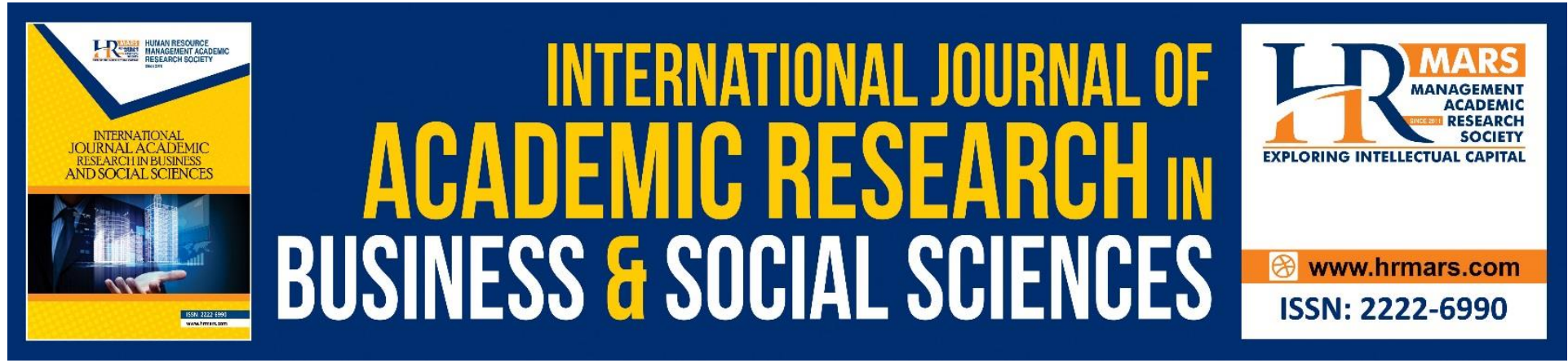

\title{
The Relationship Between E-learning During Coronavirus Pandemic and Job Burnout among Faculty Members in Public and Private Universities in Jordan
}

\author{
Shehadeh Mofleh Al-gharaibeh \\ Associate Professor, Department of Business, Jerash University, Jordan \\ Email: shehadehgh75@gmail.com \\ Dalal M. Al-Zoubi, Professor \\ Department of Education, Al-Balqa Applied University, Irbid, Jordan \\ Email: dalalzoubi@yahoo.com \\ Haitham Ali Hijazi \\ Assistant Professor, Department of Business, Jerash University, Jordan \\ Email: info@hijazi-km.com
}

\begin{abstract}
Asaad Al-Sakarneh
Assistant Professor, Department of Business, faculty of business, Jerash University, Jordan

Email: asaadalsakarneh@yahoo.com

Hamzeh Mohamed Alhawamdeh

Associate Professor, Department of Business, Jerash University, Jordan

Email: Hamzehhawamdeh@hotmail.com
\end{abstract}

\author{
Mohammad Abdel Mohsen Al-Afeef \\ Associate professor, department of financial and banking sciences, faculty of business, \\ Jerash University, Jordan \\ Email: dr.mohammad@jpu.edu.jo
}

\begin{abstract}
This study aimed to determine whether there is a relationship between the level of e-learning during the Coronavirus pandemic and job burnout among faculty members in public and private universities in Jordan, to improve the e-learning experience and make it reach the best possible levels to avoid the increased feeling of burnout among faculty members. The study population consisted of all faculty members working in Jordanian public and private
\end{abstract}


universities for the year 2021, and their number is approximately $(11,400)$ members. The unit of analysis included all academic ranks operating within the mentioned universities (Professor, Associate Professor, Assistant Professor, Lecturer). A stratified Random Sample was calculated using the university variable at $6 \%$, which is considered an appropriate proportion to represent the study population. The sample size reached 684 faculty members and a study tool (questionnaire) was distributed electronically among them. (580) questionnaires were retrieved from the sample members and (55) were excluded because they were not suitable for analysis. Therefore, the final number of questionnaires that are suitable for statistical analysis is (525) questionnaires. The study found that the level of elearning, as well as the level of burnout, were moderate among faculty members in public and private universities in Jordan. Also, the study found that the sample members' perspective of the e-learning level was similar in most of the variables except for the type of university variable (public or private), as well as for the job burnout variable, where it was similar towards most variables except for the variable of academic rank. The study concluded that there is a negative correlation with a statistical significance between the level of elearning and the level of job burnout among the study sample, in addition to the existence of a negative correlation between all areas of e-learning and all areas of job burnout.

Keywords: E-learning, Job Burnout, Faculty Members, Jordanian Universities

\section{Introduction}

In late 2019, the coronavirus appeared in China and started spreading worldwide. On March 11, 2020, the World Health Organization announced that COVID-19 was a pandemic, where Jordan, like other countries in the world, was affected by this emergency. The Jordanian government authorities announced the closure of all educational institutions at all stages in Jordan as a precautionary measure to prevent the spread of the virus among the educational sector members, both students and teachers, and thus among citizens. Therefore, the Ministries of Education and Higher Education and Scientific Research have also decided to switch to e-learning to maintain the continuity of the educational process.

\section{Research Problem}

Researchers are faculty members of both public and private Jordanian Universities, who have been in the academic field for a long time, where they have been teaching in person. With the outbreak of the Coronavirus pandemic, and in response to the instructions of the Ministry of Higher Education and Scientific Research in Jordan, they started the teaching process in its various activities using e-learning as of March 2020 until today. During their meetings, which were conducted electronically, and sometimes in person, and from their conversations, they noticed that many problems and obstacles resulted from the e-learning process, including those related to their feeling of emotional exhaustion, their feelings of depersonalization, and their unwillingness to pursue any achievement, and that these feelings started to appear after the shift to the e-learning process. The researchers returned to the literature that discussed the e-learning during the Coronavirus pandemic and found that most of these studies aimed to measure the extent of the success of the e-learning process in schools, and to a limited extent in universities, as well as the advantages and disadvantages of this type of education, and the problems it faced. Whereas all these studies were lacking any investigation on the effects of e-learning on the feelings of a faculty member while performing duty, including the feeling of job burnout. Hence, the researchers had the idea of investigating the relationship 
between e-learning during the Coronavirus pandemic and faculty members' burnout in Jordanian universities.

Therefore, the issue of the study is presented in the following main question:

"Is there a relationship between the level of e-learning during the Coronavirus pandemic and the level of burnout among faculty members in public and private universities in Jordan?"

\section{Study Questions}

The first question: What was the level of e-learning during the Coronavirus pandemic in public and private universities in Jordan from the perspective of faculty members working there?

The second question: What is the level of burnout among faculty members in public and private universities in Jordan from the perspective of faculty members working there?

\section{Research Hypotheses}

First hypothesis: There are no statistically significant differences at significance level ( $\alpha \leq 0.05)$ in the level of e-learning during the Coronavirus pandemic in public and private universities in Jordan due to the following variables for the sample members: gender, academic rank, type of university, college, years of service, social status.

Second hypothesis: There are no statistically significant differences at significance level ( $\alpha \leq$ 0.05) in the level of job burnout among faculty members in public and private universities in Jordan due to the following variables for the sample members: gender, academic rank, type of university, college, years of service, and social status.

Third hypothesis: There is no statistically significant relationship at significance level $(\alpha \leq 0.05)$ between the level of e-learning during the pandemic and the level of job burnout among faculty members in public and private universities in Jordan.

\section{Research Objectives}

Based on the study questions and assumptions, this research is designed to achieve the following objectives:

1) Determining the level of e-learning during the Coronavirus pandemic in public and private universities in Jordan, to benefit from the results in improving the e-learning process in universities and overcoming the problems that stand in the way of that success, if any.

2) Determining the level of job burnout among faculty members in public and private universities in Jordan, to benefit from the results to reduce the faculty members' feeling of job burnout if the results show that and keeping it at the required level.

3) Finding out whether there are differences in the level of e-learning during the Coronavirus pandemic in public and private universities in Jordan due to the following variables for the sample members: gender, academic rank, type of university, college, years of service, social status, to know which groups, in light of these variables, see that the success of the e-learning process has not reached the required level, and therefore try to understand their views and use them to improve this experience.

4) Finding out if there are differences in the level of job burnout among faculty members in public and private universities in Jordan due to the following variables for the sample members: gender, academic rank, type of university, college, years of service, social status, to know which groups, in light of these variables, have a stronger sense of job burnout than others, and therefore try to understand their views and use them to improve their feeling. 
5) Finding out whether there is a relationship between the level of e-learning during the Coronavirus pandemic and the job burnout of faculty members in public and private universities in Jordan, to try to improve the e-learning experience and make it reach the best possible level to avoid the increased burnout feeling of faculty members, if the results prove that there is a relationship between them.

\section{Research Importance}

The importance of this research stems from the importance of the study variables and the expected benefit that both Jordanian public and private universities can get, as well as the Ministry of Higher Education and Scientific Research in Jordan and all sectors and agencies concerned with the educational process. The importance of this research comes from the fact that it deals with one of the aspects that resulted from the spread of the Coronavirus pandemic, which the whole world is still suffering from, and that its effects extended to include the education sector in various parts of the world, however, no one knows when it will end.

During the Coronavirus pandemic, many studies have appeared that dealt with the orientation of most countries in the world towards e-learning instead of face-to-face education as one of the means to contain the pandemic and reduce the number of cases as much as possible since the educational sector is one of the most crowded and mixed sectors, which can cause the spread of virus widely and quickly. These studies aimed to identify the advantages and disadvantages of e-learning, and the problems and difficulties arising from it, and to measure its success through a survey that takes the opinions of students and teachers in schools in general.

Since the universities sector in Jordan has not been the matter of any study - according to the survey conducted by the researchers - that deals with the relationship between e-learning during the Coronavirus pandemic and job burnout among faculty members in universities, the researchers considered conducting such a study because it will add more practical knowledge about e-learning, job burnout, and the relationship that can link them. Therefore, the importance is to add theoretical knowledge for those interested and working in the sector of higher education institutions through literature, previous studies that were reviewed which were related to e-learning and job burnout, and through the study tool and the methodology that was followed to implement the study. Also, the administrations of public and private universities may benefit from the results of this study in developing plans to address any problems facing the e-learning process and the level of faculty members' sense of job burnout. The results and recommendations of this study may also draw the attention of researchers to the need for further studies on e-learning and burnout in the academic sector and other sectors.

\section{Study Background and Literature Review \\ E-Learning \\ E-learning Definition}

Studies indicate that several synonyms can be used to express e-learning such as Distance Learning, Open Learning, Online Learning, Virtual Learning, Electronic Learning, and Mobile Learning, which is learning using mobile devices and tablets. Regardless of any of these synonyms, e-learning as defined by Bakia et. al. and Means et.al. is learning that occurs in whole or in part through the Internet (Simamora, 2020). Allen \& Seaman as well as Casanova $\&$ Price also define online learning as learning which at least $80 \%$ is provided through the 
Internet (Simamora, 2020). Keis defines it as software that depends on the web to distribute, track, and manage teaching courses via the Internet (Mukhtar et. al., 2020). Sadeghi (2019) defines distance learning as one of the learning types in which the student is not always present at the study site, meaning that he learns and qualifies in the subject he has chosen via the Internet, without coming to the exam centre, college building, or university campus. In this study, researchers define e-learning, regardless of the naming, as all activities related to the learning process that is provided to students in a non-face-to-face manner, using electronic technologies and applications.

\section{The Emerging of E-learning}

Clark claims that the emergence of distance learning applications dates back 300 years when lessons were mailed weekly to students in the United States, whereas Burns argues that Great Britain, Switzerland, and Australia provided distance education through mail, radio, and television due to the geographic expansion of these countries (Sari and Nayir, 2020). Mayer and Birnbaum explain that the origins of distance learning go back a hundred years, when the early distance learning materials used the first and second generations of communication technology, where the first generation extending between (1850 - 1960) consisted of printed materials, radio, and television, while the second generation (1960 - 1985) used other technologies except for the computer, and these technologies consisted of audio cassette tapes, videotapes, fax, television, as well as printed materials, adding that those who benefited from distance learning were students in rural and remote areas, in addition to army soldiers, especially those who are forced to leave school because of their assignments outside their country which happened in the first and second world wars (Sadeghi, 2019).

\section{E-learning Advantages}

Studies have shown that many benefits can be achieved by transitioning to e-learning, regardless of what reason is behind the transition. Among these advantages is that e-learning takes place away from the restrictions of time and place, and according to the times that students and teachers deem appropriate for them (Simamora, 2020; Fatoni et. Al., 2020; Dhawan, 2020; Sadeghi, 2019) which ensures the continuity of the learning system and helps learners to return to lectures at any time they want, given that the lectures are usually recorded (Mukhtar et. al., 202 0). Also, distance learning helps to invest time in a better way as it eliminates or reduces the time that students and teachers need to move to and from the place of study (Fatoni et. al., 2020; Sadeghi, 2019) as well as reducing the financial costs of that movement (Fantoni et. al., 2020; Sadeghi, 2019), in addition to the possibility of investing time in practicing a job or work while learning at the same time (Sadeghi. 2019). Suryaman et. al, (2020) see that e-learning helps students spend more time with their families, which leads to strengthening emotional relationships between parents and children. Another advantage of applying the e-learning system is that such learning provides teachers with the ability to constantly update the material (Simamora, 2020), offers a comfortable learning environment (Fatoni et. al., 2020), gives teachers the chance to get instant feedback (Dhawan, 2020), enables the teacher to diversify teaching methods from audio, video, etc... (Dhawan, 2020), gives students the flexibility to choose study programs (Sadeghi, 2019), enables students to talk freely with teachers using chat more than if learning was face-to-face (Fatoni et. par., 2020), and finally reduces the risk of catching the virus (Suryaman et al., 2020). 


\section{E-learning Disadvantages}

At the same time, studies have indicated that there are many disadvantages to e-learning. With regards to the technical aspects and the electronic infrastructure, studies have indicated that the most prominent problems are the instability of the Internet, the interruption of the teacher's voice, the delay in entering the live lecture, the lack of synchronization between the audio and the educational material, and the inability to access the Internet as some areas don't even have Internet access (Fatoni et. al., 2020, Baticulon et. al., 2020; Dubey \& Pandey, 2020; Reyes-Chua et. al., 2020; Grishchenko cited in Lembani et al.,2020; Sari \& Nayir, 2020; Hayashi et. al., 2020). As pointed out by Simamora (2020), this type of education, as well as the platforms used in it, may not be suitable for all educational disciplines. Also, there are other technical difficulties represented in the outdated computers of students and teachers and the inability of these devices to use modern software (Dhawan, 2020; Sari \& Nayir, 2020; Sari \& Nayir, 2020). In fact, those difficulties include students and teachers not having the necessary tools, such as computers, and cannot afford the costs of accessing the Internet (Baticulon et. al., 2020; Ferraro et. al., 2020; Sadeghi, 2019; Reyes-Chua et. al., 2020; Dubey \& Pandey, 2020; Hayashi et. al., 2020), the lack of technical skills by teachers and students (Baticulon et. Al., 2020), the lack of readiness of many developing countries for e-learning (Alipio, 2020), as well as the lack technical skills for parents which are needed to help their children (Fatoni et. al., 2020).

As for what could negatively affect the learning process because of using e-learning, the problem appears to be in the absence and/or low level of communication and interaction between students and teachers, and the teachers' inability to determine whether students take learning seriously (Fatoni et. al., 2020; Mukhtar et. al., 2020; Baticulon et. al., 2020, Sadeghi, 2019; Suryaman et. Et al., 2020; Sari \& Nayir, 2020), the low concentration rate as students cannot focus for a long period (Fatoni et. al., 202; Mukhtar et. al., 2020), the note that there is a good level of distraction, frustration, anxiety, and confusion among students (Dhawan. 2020; Sadeghi, 2019), the difficulty of adapting to the electronic learning style, whether it is from students or teachers (Baticulon et. al., 2020; Reyes-Chua et. Al., 2020; Dubey \& Pandey, 2020; Chakraborty et. Al., 2020), the lack of interest in building the student's personality, as there are no activities that support personality development, given that the focus is on the learning process or the transfer of knowledge, in addition to the difficulty of providing students with the necessary skills for them (Suryaman et. al., 2020; Mukhtar et. al., 2020), the lack of readiness of the approved curricula, Pedagogy, and exams process for elearning (Hayashi et. al., 2020), the lack of practical effectiveness of the exams (Martin, 2020), the bad behaviour of some students during the lecture (Mukhtar et. Al., 2020) as well as the lack of technological skills for teachers (Baticulon et. al., 2020; Reyes- Chua et. Al., 2020). In addition, it was noted that there are severe educational difficulties for students with special needs (Fatoni et. al., 202).

Studies conducted on the reality of e-learning during the Coronavirus pandemic have revealed the existence of many difficulties and challenges resulting from the trend to use this type of education. It was found that teachers were exposed to a high degree of fatigue and faced health issues (headache, tired eyes) because of their long stays in front of screens to prepare and present the educational material. As for the students, it was found that there has been an increase in the cases of psychological and mental disorders, depression, stress, anxiety, and deviation. As well as students lacking motivation and growth of negative emotions, inability to follow up on the screen, feeling of isolation, and lack of integration (Baticulon et. 
al., 2020; Ferraro et. al., 2020; Fatoni et. al., 2020; Sari \& Nayir, 2020; Foundation for good practice, 2020).

Also, the trend towards e-learning, especially during the Coronavirus pandemic, has resulted in more challenges and complications, represented in students and teachers having to carry out more burdens and meet household needs while being involved in the learning process at the same time, especially during periods of a lockdown (Baticulon et. al., 2020), the occurrence of family problems due to the long stay of teachers and students at home (Baticulon et. al., 2020), adding a new burden to parents because they became teachers, observers, and helpers in solving activities and homework (Arwen et. et al., cited in Suryaman et al. Alal., 2020), in addition to all this, there is not enough space for learning at home, and homes lack an appropriate disciplinary environment that provides a comfortable atmosphere for learning (Baticulon et. Et al., 2020; Patricia cited in Lembani etal. al., 2020; Sari \& Nayir, 2020; Fatoni et. al., 2020).

\section{Job Burnout}

Job burnout is a relatively modern administrative concept, and the first appearance of this term was in the seventies of the last century. Job burnout represents a major obstacle that prevents the individual from carrying out his work as expected or as hoped for (Al- Hindi \& AlQurashi, 2021). Job burnout has been defined as a negative phenomenon that individuals are exposed to because of the inability to work, which leads to their feeling of inability to solve problems, and thus loss of interest in work and feeling of psychological tension while carrying it out (Al- Hindi \& Al-qurashi, 2021). Researchers define it as an internal state ranging from anger to anxiety, which is generated because of the emergence of factors related to the work environment such as work pressure that leads to the individual feeling emotional exhaustion, depersonalization, and lack of ability to achieve personal accomplishments.

\section{Job Burnout Dimensions}

There are multiple dimensions to job burnout of which the most important, according to the researchers' consent, are: (Yang et. al, 2021; Gill, 2017, 61; Al-Jaf, 2020,358; Beyouk,2015; AlHindi and Al-qurashi, 2021,29):

- $\quad$ Emotional Exhaustion [Occupational]: is the basis of job burnout and the main factor that accumulates in job burnout, which is the individual's feeling that he is stressed due to the lack of emotional resources.

- Depersonalization: is the most extensive dimension of job burnout, which is the negative attitudes towards others and the individual's lack of any feeling towards the people he deals with. Some of these dimension symptoms are cruelty, pessimism, frequent criticism, sarcasm, blaming others, and disregarding the feelings of others.

- Low Personal Accomplishment: which builds up due to feeling emotional stress and aggressive responses towards others, making the individual feel that he is unable to perform the tasks assigned to him and resulting in a lack of self-esteem and thus the inability to work under pressure.

\section{Job Burnout Stages}

Job burnout, like other managerial behaviours, goes through sequential stages (Al- Hindi and Al-qurashi 2021) as follows:

1. Absorption stage, where the level of job satisfaction is high, but there is a difference between reality and what was expected, and the level of satisfaction begins to decline. 
2. Depersonalization stage, and this stage grows slowly where the level of job satisfaction gradually decreases, and the efficiency of work performance and level of achievement decreases. The individual feels physically ill and begins to shift his interest to other things in life such as social contacts and hobbies, in order to fill his void.

3. The stage of separation, where at this stage the individual realizes what happened and begins to withdraw psychologically, and feels mentally and physically ill, with an increase in the feeling of psychological stress.

4. The critical stage, which is the most difficult and farthest stage in job burnout, where psychological, physical, and behavioural symptoms worsen, and their danger increases. Individual's thinking is disrupted, and his self-doubt increases, reaching the stage of invasion (explosion) and then thinks of leaving his work, and it may even reach the point of considering suicide.

\section{Study Methodology \\ Study Approach}

This study is a correlative study, and the descriptive correlative approach has been followed to achieve its objectives. It is a descriptive study because it describes the reality and level of e-learning practices in Jordanian public and private universities, as well as the level of job burnout. It is also a correlative study, as it studies the relationship between the level of elearning process and job burnout level among faculty members in Jordanian public and private universities.

\section{Study Population and Sample}

The study population consisted of all faculty members working in Jordanian public and private universities for the year 2021, and their number is $(11,400)$ members. The unit of analysis included all academic ranks operating in the mentioned universities (professor, associate professor, assistant professor, lecturer). Since the study population is one of the large populations, a stratified random sample was derived according to the university variable by $6 \%$, which is considered an appropriate proportion to represent the study population (Sekaran \& Bougie, 2010). The number of sample members reached (684) faculty members; the study tool (the questionnaire) was distributed to them electronically. (580) questionnaires were retrieved from the sample members, and 55 of them were excluded because they were not suitable for analysis. Therefore, the final number of questionnaires suitable for statistical analysis is (525). Table No. (1) shows the distribution of the sample members in the light of the intermediate variables. 
INTERNATIONAL JOURNAL OF ACADEMIC RESEARCH IN BUSINESS AND SOCIAL SCIENCES Vol. 11, No. 11, 2021, E-ISSN: 2222-6990 ๑ 2021 HRMARS

Table 1: Study Sample

\begin{tabular}{|c|c|c|c|c|c|}
\hline Variables & Level of Variables & Frequency & $\begin{array}{l}\text { Percent } \\
\%\end{array}$ & $\begin{array}{l}\text { Valid } \\
\text { Percent \% }\end{array}$ & $\begin{array}{l}\text { Cumulative } \\
\text { Percent \% }\end{array}$ \\
\hline \multirow[t]{3}{*}{ Gender } & Female & 126 & 24.0 & 24.0 & 24.0 \\
\hline & Male & 399 & 76.0 & 76.0 & 100.0 \\
\hline & Total & 525 & 100.0 & 100.0 & \\
\hline \multirow{5}{*}{$\begin{array}{l}\text { Academic } \\
\text { Rank }\end{array}$} & Professor & 123 & 23.4 & 23.4 & 23.4 \\
\hline & Associate Professor & 147 & 28.0 & 28.0 & 51.4 \\
\hline & Assistant Professor & 177 & 33.7 & 33.7 & 85.1 \\
\hline & Lecturer & 78 & 14.9 & 14.9 & 100.0 \\
\hline & Total & 525 & 100.0 & 100.0 & \\
\hline \multirow{3}{*}{$\begin{array}{l}\text { University } \\
\text { type }\end{array}$} & Public & 288 & 54.9 & 54.9 & 54.9 \\
\hline & Private & 237 & 45.1 & 45.1 & 100.0 \\
\hline & Total & 525 & 100.0 & 100.0 & \\
\hline \multirow[t]{3}{*}{ College } & Humanities & 333 & 63.4 & 63.4 & 63.4 \\
\hline & Scientific & 192 & 36.6 & 36.6 & 100.0 \\
\hline & Total & 525 & 100.0 & 100.0 & \\
\hline \multirow{3}{*}{$\begin{array}{l}\text { Years of } \\
\text { Experience }\end{array}$} & 10 years or less & 198 & 37.7 & 37.7 & 37.7 \\
\hline & More than 10 years & 327 & 62.3 & 62.3 & 100.0 \\
\hline & Total & 525 & 100.0 & 100.0 & \\
\hline \multirow[t]{3}{*}{ Social Status } & Married & 483 & 92.0 & 92.0 & 92.0 \\
\hline & Other & 42 & 8.0 & 8.0 & 100.0 \\
\hline & Total & 525 & 100.0 & 100.0 & \\
\hline
\end{tabular}

The above table shows that $76 \%$ of the sample members were males and the rest are females. Also, it was found that $34 \%$ of the sample members were assistant professors followed by associate professors. Moreover, $54.9 \%$ of the sample members were working in public universities; $63.4 \%$ is working in Humanities faculties; $62.3 \%$ have experience for more than 10 years and $92 \%$ of the sample members were married.

\section{Study Tool}

This study was based on two main sources for collecting the required data: secondary sources, and primary sources represented by a questionnaire that was designed to achieve the objectives of the study. The design of the study tool (the questionnaire) was based on the previous literature, especially the part related to job burnout, where the scale of job burnout that was developed earlier was used (Maslach \& Jackson, 1981), and has been Arabized and used in previous research (Hijazi et. Et al., 2021). While the researchers built the scale related to e-learning. The questionnaire consisted of (70) items that measure e-learning and job burnout, as follows: 
INTERNATIONAL JOURNAL OF ACADEMIC RESEARCH IN BUSINESS AND SOCIAL SCIENCES

Vol. 11, No. 11, 2021, E-ISSN: 2222-6990 @ 2021 HRMARS

Table 2: Study Tool

\begin{tabular}{|l|l|l|l|}
\hline \multicolumn{4}{|l|}{ Scales } \\
\hline $\begin{array}{l}\text { No. of } \\
\text { items }\end{array}$ & Job burnout scale/ Areas & $\begin{array}{l}\text { No. of } \\
\text { items }\end{array}$ & E-learning scale/ Areas \\
\hline 7 & Emotional Exhaustion & 15 & Infrastructure \\
\hline 5 & Depersonalization & 13 & $\begin{array}{l}\text { The effectiveness of the educational } \\
\text { process }\end{array}$ \\
\hline 8 & $\begin{array}{l}\text { Personal } \\
\text { Accomplishment }\end{array}$ & 8 & Student achievement assessment \\
\hline 20 & & 14 & The effectiveness of e-learning \\
\hline
\end{tabular}

Validity and Reliability of Research Tools

Validity Test

To test the validity of the study tool, the questionnaire was presented to several specialized arbitrators to ensure the clarity of the questionnaire's paragraphs and the ability to understand it. Based on the comments received, the necessary modifications were made.

\section{Reliability Test}

Cronbach Alpha was used to test the consistency of the questionnaire. The following table shows that the Alpha value for each variable is greater than the accepted value $(0.60)$ that reflects the consistency of the questionnaire (Sekaran \& Bougie, 2016)

Table 3: Consistency of Research Tool (Cronbach Alpha)

\begin{tabular}{|l|l|l|l|}
\hline E-learning/ Areas & Alpha value & Job burnout / Areas & Alpha value \\
\hline Infrastructure & 0.929 & Emotional Exhaustion & 0.883 \\
\hline The effectiveness of the educational process & 0.934 & Depersonalization & 0.867 \\
\hline Student achievement assessment & 0.886 & $\begin{array}{l}\text { Personal } \\
\text { Accomplishment }\end{array}$ & 0.834 \\
\hline The effectiveness of e-learning & 0.942 & & \\
\hline
\end{tabular}

\section{Study Tool}

To calculate the total score for each scale, (5) alternatives have been developed for the respondent to choose one that expresses his opinion, and these alternatives range from 1 5. To determine the level of the arithmetic averages of the items and areas for both scales in the tool, the statistical standard was adopted using the following equation:

Upper limit of the scale (5) - Lower limit of the scale (1) / number of classes required Number of classes required (3)

And then add the answer (1.33) to the end of each class

\begin{tabular}{|l|l|}
\hline Means & Level \\
\hline $1.00-2.33$ & Low \\
\hline $2.34-3.67$ & Moderate \\
\hline $3.68-5.00$ & High \\
\hline
\end{tabular}




\section{Research Variables}

This study consisted of several variables as follows:

- Independent variable: The level of e-learning in its dimensions (infrastructure, effectiveness of the educational process, student achievement assessment, effectiveness of e-learning) in Jordanian public and private universities.

○ Dependent variable: The level of job burnout with its dimensions (emotional exhaustion, depersonalization, personal accomplishment) among faculty members in Jordanian private-public universities.

$\circ \quad$ Secondary independent Variables (Intermediate): Gender, academic rank, university type, college, years of service, social status

\section{Statistical Methods Used}

To answer the questions of the study, examine its hypotheses, and reach the results and recommendations that achieve the objectives of the study, arithmetic averages and standard deviations were used to answer the first and second questions, and Six-sided ANOVA method was used to test the first and second hypotheses. Pearson correlation coefficient was used to test the third hypothesis.

\section{Data analysis and Discussion}

\section{The First Question}

"What was the level of e-learning during the Coronavirus pandemic in public and private universities in Jordan from the perspective of faculty members working there?"

To determine the level of e-learning during the Coronavirus pandemic in public and private universities, the arithmetic averages for the scale and each of the fields was extracted as shown in Table 4 below (for the arithmetic averages of the paragraphs, see Appendix No. 1):

Table 4: Means, Std deviations and levels of e-learning and its areas

\begin{tabular}{|l|l|l|l|l|l|l|}
\hline E-learning/ areas & N & Minimum & Maximum & Mean & $\begin{array}{l}\text { Std. } \\
\text { Deviation }\end{array}$ & level \\
\hline Infrastructure & 525 & 1.00 & 5.00 & 3.68 & .71 & High \\
\hline $\begin{array}{l}\text { The effectiveness of the } \\
\text { educational process }\end{array}$ & 525 & 1.08 & 4.85 & 2.65 & .79 & Moderate \\
\hline $\begin{array}{l}\text { Student achievement } \\
\text { assessment }\end{array}$ & 525 & 1.00 & 5.00 & 2.40 & .83 & Moderate \\
\hline $\begin{array}{l}\text { The effectiveness of e- } \\
\text { learning }\end{array}$ & 525 & 1.00 & 4.79 & 2.39 & .85 & Moderate \\
\hline E-learning (Total) & 525 & 1.06 & 4.72 & 2.85 & .68 & Moderate \\
\hline
\end{tabular}

It is evident from Table No. 4 above that the overall level of e-learning during the Coronavirus pandemic in public and private universities in Jordan, was moderate. The e-learning level in most areas was moderate as well, except for the field of infrastructure, which came high with the highest arithmetic average, followed by the field of the effectiveness of the educational process, and then the field of student achievement assessment, and it was the lowest for the field of e-learning effectiveness.

The overall result, which came at a moderate level, indicates that public and private universities are moderately suffering from e-learning during the Coronavirus pandemic, and this is a significant matter given the importance of the continuity in the education process in universities under emergency conditions and in a way that meets the aspirations and goals of 
these universities in maintaining the quality of graduates and their possession of the necessary skills and abilities that qualify them to enter the labour market with strength and professionalism. Therefore, this result needs the university administration to pay attention to it, because of its impact on the performance of faculty members and the performance of students, and thus the performance of the university. This result may be explained by the presence of weakness in the skills of e-learning among faculty members and students as well. This is due to many factors, the most prominent one was the lack of use of e-learning previously by many faculty members and students, as universities administration did not focus on this subject and did not make it one of the basic requirements in education. Before the pandemic, face-to-face education was dominant, and using e-learning was at a low level by many in these universities, even though most universities provided appropriate infrastructure, educational platforms, and Internet subscriptions, which was referred to by the first field (infrastructure) that came at a high level. The sample members indicated, through their answers on the e-learning scale, the ease of entry and exit from the educational platform and the ease of exchanging educational materials between teachers and students, as well as the university's provision of appropriate technical support to facilitate the process of learning and teaching.

As for the other three fields (the effectiveness of the educational process, assessment of student achievement, and the effectiveness of e-learning), which got a moderate level, this may be due to the difficulty of good communication between teachers and students for various reasons, the most prominent ones are technical problems on the Internet for students mostly because their places of residence are geographically distributed over areas near and far so that the network coverage is not the same for everyone. Also, the universities did not support students by providing them with the Internet, and many students from a low economic level cannot afford Internet throughout the week, which sometimes pushes them to miss lessons. Moreover, the degree of supervision during lessons is not at the appropriate level due to the difficulty of determining the reasons for not attending classes or exams, where some of them claim that interruptions occur constantly and must re-enter more than once, in addition to other factors and reasons. It must be pointed out that the educational environment in e-learning is not completely suitable, especially for students. As known, family structure in the Jordanian community doesn't give students enough privacy due to large families' sizes, having more than one family member in the same room, having more than one student at the same family who is using the internet at the same time which makes it weak, in addition to the lack of personal devices for each student in many poor families. All these factors make the interaction between students and teachers more difficult than face-to-face education. Moreover, the large number of students in many academic courses and the difficulty of controlling cheating and safety procedures during exams led to the evaluation results being somewhat unreal. The most important issue is not giving each student enough time to interact, express his opinion, and participate, which may be difficult under these circumstances, especially the interaction between the students themselves. Therefore, if universities want the success of e-learning, they must make appropriate arrangements for teachers and students, and support students with sufficient internet devices and cards, in addition to studying the conditions of students and solving their various problems. Otherwise, the process will remain to be appropriate sometimes and inappropriate the other times, affecting the motivations of students and teachers towards learning and teaching, and affecting the social relations for each of them which were marred by some defects resulting from the shift from face-to-face education to e-learning. 


\section{The Second Question}

"What is the level of burnout among faculty members in public and private universities in Jordan from the perspective of faculty members working there?"

To determine the level of job burnout among faculty members in public and private universities, the arithmetic averages for the scale and each of the fields was extracted as shown in Table 5 below (for the arithmetic averages for the paragraphs, see Appendix No. 2):

Table 5: Means, Std deviations and levels of Job burnout and its areas.

\begin{tabular}{|l|l|l|l|l|l|l|}
\hline Job burnout/ areas & $\mathbf{N}$ & Minimum & Maximum & Mean & $\begin{array}{l}\text { Std. } \\
\text { Deviation }\end{array}$ & level \\
\hline Emotional Exhaustion & 525 & 1.00 & 4.86 & 3.11 & .88 & Moderate \\
\hline Depersonalization & 525 & 1.00 & 5.00 & 2.54 & .90 & Moderate \\
\hline $\begin{array}{l}\text { Personal } \\
\text { Accomplishment }\end{array}$ & 525 & 1.00 & 5.00 & 2.82 & .76 & Moderate \\
\hline Job burnout (Total) & 525 & 1.00 & 4.95 & 2.85 & .75 & Moderate \\
\hline
\end{tabular}

It is evident from Table No. 5 above that the overall Job Burnout level among faculty members at public and private universities was moderate. The level of job burnout was in all fields (emotional exhaustion. depersonalization, and personal accomplishment) moderate, where the highest level was for the emotional exhaustion field followed by the personal accomplishment field and then by the depersonalization.

This result indicates that faculty members in public and private universities suffer moderately from job burnout in general, an insignificant result which university administration needs to pay attention to because of its impact on the performance of faculty members and thus the performance of the university in general. This result may be is because the university doesn't give sufficient and appropriate attention and support to faculty members, which is represented by support and understanding of their feelings and desires regarding work, and the relationship between the university and faculty members and among the faculty members themselves. Individuals constantly need emotional support in various situations, including work situations, and the individual's feeling that those around him are supportive, especially if a problem arises for him that needs support to overcome it, makes it easier for him to deal with these situations and problems in the best possible way, which therefore affects his psychological and physical health, and ultimately, affects his general performance. Also, the moderate level of accomplishment is the biggest evidence that the university administration does not provide sufficient support to its faculty members, as it must encourage and motivate them to develop and research in their fields. If faculty members do not find appreciation and gratitude for the personal efforts they make, they will feel that what they do is not important to the university, and their achievement will decline without realizing it.

As for the two fields (emotional exhaustion and depersonalization), which were at moderate levels, this may be because the faculty members in universities are usually people with a degree of knowledge and discipline that qualified them to reach this academic rank and therefore they have the necessary psychological balance that protects them from reaching depersonalization, as the profession of a faculty member in Jordan is considered one of the professions that receive great respect from the community, resulting in a significant impact on the faculty member's self-satisfaction and his satisfaction with his profession, which helps to balance his feelings and not give in to feel negative. 


\section{The First Hypothesis (H1)}

"There are no statistically significant differences at significance level $(\alpha \leq 0.05)$ in the level of e-learning during the Coronavirus pandemic in public and private universities in Jordan due to the following variables for the sample members: gender, academic rank, type of university, college, years of service, social status."

To identify the differences in the sample members perspectives on the level of e-learning during the Coronavirus pandemic in public and private universities according to the intermediate variables, the arithmetic averages and standard deviations of their answers were extracted considering these variables, and then an ANOVA test was conducted as shown in Tables No. 6 and 7, and as follows:

Table 6: Means and Std. Deviation for E-learning according to intermediate variables

\begin{tabular}{|c|c|c|c|c|}
\hline Variables & Level of Variables & $\mathbf{N}$ & Mean & Std. Deviation \\
\hline \multirow[t]{3}{*}{ Gender } & Female & 126 & 2.92 & .577 \\
\hline & Male & 399 & 2.82 & .710 \\
\hline & Total & 525 & 2.85 & .681 \\
\hline \multirow[t]{5}{*}{ Academic Rank } & Professor & 123 & 2.84 & .721 \\
\hline & Associate Professor & 147 & 2.81 & .691 \\
\hline & Assistant Professor & 177 & 2.87 & .646 \\
\hline & Lecturer & 78 & 2.88 & .685 \\
\hline & Total & 525 & 2.85 & .681 \\
\hline \multirow[t]{3}{*}{ University type } & Public & 288 & 2.78 & .685 \\
\hline & Private & 237 & 2.93 & .668 \\
\hline & Total & 525 & 2.85 & .681 \\
\hline \multirow[t]{3}{*}{ College } & Humanities & 333 & 2.88 & .728 \\
\hline & Scientific & 192 & 2.79 & .587 \\
\hline & Total & 525 & 2.85 & .681 \\
\hline \multirow{3}{*}{$\begin{array}{l}\text { Years of } \\
\text { Experience }\end{array}$} & 10 years or less & 198 & 2.85 & .665 \\
\hline & More than 10 years & 327 & 2.84 & .692 \\
\hline & Total & 525 & 2.85 & .681 \\
\hline \multirow[t]{3}{*}{ Social Status } & Married & 483 & 2.83 & .672 \\
\hline & Other & 42 & 3.01 & .764 \\
\hline & Total & 525 & 2.85 & .681 \\
\hline
\end{tabular}


Table 7: Tests of Between-Subjects Effects

Dependent Variable: E-learning

\begin{tabular}{|l|l|l|l|l|l|}
\hline Source & $\begin{array}{l}\text { Type III Sum } \\
\text { of Squares }\end{array}$ & df & Mean Square & F & Sig. \\
\hline Gender & .516 & 1 & .516 & 1.124 & .290 \\
\hline Academic Rank & .150 & 3 & .050 & .109 & .955 \\
\hline University Type & 3.349 & 1 & 3.349 & 7.289 & $.007^{*}$ \\
\hline College of & .188 & 1 & .188 & .410 & .522 \\
\hline $\begin{array}{l}\text { Years } \\
\text { Experience }\end{array}$ & .373 & 1 & .373 & .811 & .368 \\
\hline Social Status & .669 & 1 & .669 & 1.456 & .228 \\
\hline Error & 237.097 & 516 & .459 & & \\
\hline Corrected Total & 243.081 & 524 & & & \\
\hline
\end{tabular}

$\alpha \leq 0.05$

The results indicated by Table (7) confirm that faculty members perspective on the level of elearning in public and private universities is similar in most variables, except for the universitytype variable. The gender variable result may be explained as the sample members, whether male or female, live in the same university educational environment and the same instructions and requirements related to e-learning are applied to them, meaning that there is no difference in the requirements or conditions of application or educational or evaluation procedures according to the gender of the teacher. Therefore, their perspective on the level of e-learning was similar. As for the similarity of perspective for sample members according to the academic rank variable, this may be because the e-learning experience is a new experience to all faculty members and students as well, and its use was previously limited to some educational tasks and activities for some faculty members, and not everyone. Therefore, this experience is considered new for most of them, regardless of their academic rank, and this justifies the similarity in the views of the sample members, regardless of their academic rank. In terms of college variable, whether it is scientific or humanitarian, the similarity may also be explained in the perspective of the sample members as the university administration does not discriminate when dealing with members according to their specializations in terms of the requirements and procedures of e-learning, because each teacher is required to perform his educational tasks and duties electronically, and to try to make this process succeed, whether his specialization is scientific or humanitarian, as this is the right of the student, regardless of the specialization. As for the variable years of experience and the similarity in the perspectives of the sample members, the similarity may be because the sample members' evaluation of the reality of e-learning in universities is not related to their years of experience as the e-learning experience is new to everyone with many, medium, or few years of experiences. What faculty members face during this experience, whether it is related to interaction with students, how to implement lessons and assignments, students' reactions, the method of evaluating students, and other processes related to e-learning, are the same for all faculty members regardless of their years of experience.

The similarity in the sample members perspectives concerning the social status variable may stem from the fact that the conditions, requirements, procedures, and objectives of elearning are the same, and faculty members are required to adhere to them to make the process successful, regardless of their social status. However, it must be noted that it may be easier for unmarried teachers who do not have family ties to deal with e-learning in an easier 
way than others, but this does not negate that every faculty member must complete his duties completely regardless of his social status, therefore, the views of the sample members were similar.

The only variable that showed statistically significant differences is the university type variable (public, private) in favour of private universities, which means that there is a difference in the sample members perspective who are working in private universities about the level of e-learning from their counterparts working in public universities, as they see that the level of e-learning is higher from the point of view of workers in public universities. This may be because private universities have freedom of spending, with easier procedures than public universities as they are owned by people, which makes it easier for them to deal with developments and emergency conditions that need speed in movement. The Coronavirus pandemic generated emergency conditions that required the university to expand its networks and find new educational platforms to suit the requirements of the educational process in its new image, which means more spending and more quick and easy procedures in a short time. It is known that most public universities in Jordan suffer financially and have accumulated debts and resort to rationalizing spending and searching for new funding sources to reduce their financial problems. Therefore, the transition to e-learning resulted in new spending, which affected universities' ability to reconcile between the necessity of elearning success and its financial ability. Whereas the financial problems in private universities exist to a much lesser extent because, in the end, they are profitable universities, so this result was logical and consistent with the reality of public and private universities.

\section{The Second Hypothesis ( $\mathbf{H 2})$}

"There are no statistically significant differences at significance level $(\alpha \leq 0.05)$ in the level of job burnout among faculty members in public and private universities in Jordan due to the following variables for the sample members: gender, academic rank, type of university, college, years of service, and social status."

To identify the differences in the sample members' perspectives on the level of job burnout among faculty members in public and private universities according to the intermediate variables, the arithmetic averages and standard deviations of their answers were extracted considering these variables, and then an ANOVA test was conducted as shown in Tables No. (8 and 9): 
Table 8: Means and Std. Deviation for Job burnout according to intermediate variables

\begin{tabular}{|c|c|c|c|c|}
\hline Variables & Level of Variables & $\mathbf{N}$ & Mean & Std. Deviation \\
\hline \multirow[t]{3}{*}{ Gender } & Female & 126 & 2.87 & .802 \\
\hline & Male & 399 & 2.84 & .732 \\
\hline & Total & 525 & 2.85 & .748 \\
\hline \multirow[t]{5}{*}{ Academic Rank } & Professor & 123 & 2.89 & .811 \\
\hline & Associate Professor & 147 & 2.64 & .621 \\
\hline & Assistant Professor & 177 & 2.94 & .769 \\
\hline & Lecturer & 78 & 2.98 & .748 \\
\hline & Total & 525 & 2.85 & .748 \\
\hline \multirow[t]{3}{*}{ University type } & Public & 288 & 2.81 & .775 \\
\hline & Private & 237 & 2.90 & .714 \\
\hline & Total & 525 & 2.85 & .748 \\
\hline \multirow[t]{3}{*}{ College } & Humanities & 333 & 2.85 & .751 \\
\hline & Scientific & 192 & 2.85 & .746 \\
\hline & Total & 525 & 2.85 & .748 \\
\hline \multirow{3}{*}{$\begin{array}{ll}\text { Years of } \\
\text { Experience }\end{array}$} & 10 years or less & 198 & 2.96 & .792 \\
\hline & More than 10 years & 327 & 2.78 & .713 \\
\hline & Total & 525 & 2.85 & .748 \\
\hline \multirow[t]{3}{*}{ Social Status } & Married & 483 & 2.86 & .754 \\
\hline & Other & 42 & 2.77 & .689 \\
\hline & Total & 525 & 2.85 & .748 \\
\hline
\end{tabular}

Table 9: Tests of Between-Subjects Effects

Dependent Variable: Job burnout

\begin{tabular}{|l|l|l|l|l|l|}
\hline Source & $\begin{array}{l}\text { Type III Sum } \\
\text { of Squares }\end{array}$ & df & Mean Square & $\mathbf{F}$ & Sig. \\
\hline Gender & .018 & 1 & .018 & .032 & .858 \\
\hline Academic Rank & 6.992 & 3 & 2.331 & 4.270 & $.005^{*}$ \\
\hline University type & .029 & 1 & .029 & .053 & .817 \\
\hline College & .002 & 1 & .002 & .004 & .949 \\
\hline $\begin{array}{l}\text { Years } \\
\text { Experience }\end{array}$ & 1.107 & 1 & 1.107 & 2.028 & .155 \\
\hline Social Status & .582 & 1 & .582 & 1.066 & .302 \\
\hline Error & 281.656 & 516 & .546 & & \\
\hline Corrected Total & 293.385 & 524 & & & \\
\hline
\end{tabular}

$$
\alpha \leq 0.05
$$

It is clear from Table 9 that there are no statistically significant differences at the level of significance $(\alpha \leq 0.05)$ in the sample members' perspectives for all intermediate variables except for the academic rank variable. To determine the source of the differences, a dimensional comparison test (Scheffe test) was conducted as shown in Table 10.

The results indicated by Table 9 confirm that the faculty members perspective on their level of job burnout is similar in most variables, except for the academic rank variable. The results regarding the gender variable may explain that the sample members, whether male or female, live in the same university organizational environment, and the same laws, regulations, and instructions are applied to them. Therefore, their point of view on the level 
of job burnout was similar. The same applies to the variable of the type of university, which showed a similarity between the views of the sample members from public and private universities. This may be because both types of universities are subject to the same regulations and instructions approved by the Higher Education Council. Hence, we do not find any fundamental differences between the environment of public and private universities. As for the college variable, whether it is scientific or humanitarian, the similarity in the viewpoint of the sample members may be explained because there is no discrimination in dealing with faculty members in terms of their specializations by the university administration, as there are instructions and regulations that preserve their rights and define their duties regardless of their specializations.

Regarding the years of experience variable, and the similarity in the sample members perspective, it may be because the feeling of job burnout is not determined by the passage of years, but by the events and situations that the individual may be exposed to, whether his experience is little or great. As for the similarity in the sample members perspectives regarding the variable of social status, it may stem from the Jordanian society, as the level of interdependence among its members, especially those who are related to each other, is high, as the person, whether married or unmarried, receives social and psychological help and support with the same level from people around him. Therefore, their feeling of the same level of burnout is not surprising.

Table 10: Post Hoc Tests/ Multiple Comparisons

Scheffe

Dependent Variable: Job Burnout

\begin{tabular}{|c|c|c|c|c|c|c|}
\hline \multirow{2}{*}{$\begin{array}{l}\text { (I) } \\
\text { Academic } \\
\text { Rank }\end{array}$} & \multirow{2}{*}{$\begin{array}{ll}\text { (J) } & \text { Academic } \\
\text { Rank } & \end{array}$} & \multirow{2}{*}{$\begin{array}{l}\text { Mean } \\
\text { Difference } \\
(\mathrm{I}-\mathrm{J})\end{array}$} & \multirow{2}{*}{$\begin{array}{l}\text { Std. } \\
\text { Error }\end{array}$} & \multirow[t]{2}{*}{ Sig. } & \multicolumn{2}{|c|}{ 95\% Confidence Interval } \\
\hline & & & & & $\begin{array}{l}\text { Lower } \\
\text { bound }\end{array}$ & $\begin{array}{l}\text { Upper } \\
\text { bound }\end{array}$ \\
\hline \multirow[t]{3}{*}{ Professor } & $\begin{array}{l}\text { Associate } \\
\text { professor }\end{array}$ & .251 & .090 & .052 & .00 & .50 \\
\hline & $\begin{array}{l}\text { Assistant } \\
\text { professor }\end{array}$ & -.054 & .087 & .942 & -.30 & .19 \\
\hline & lecturer & -.088 & .107 & .879 & -.39 & .21 \\
\hline \multirow{3}{*}{$\begin{array}{l}\text { Associate } \\
\text { professor }\end{array}$} & Professor & -.251 & .090 & .052 & -.50 & .00 \\
\hline & $\begin{array}{l}\text { Assistant } \\
\text { professor }\end{array}$ & $-.305\left(^{*}\right)$ & .082 & $.004^{*}$ & -.54 & -.07 \\
\hline & lecturer & $-.339\left(^{*}\right)$ & .103 & $.014^{*}$ & -.63 & -.05 \\
\hline \multirow{3}{*}{$\begin{array}{l}\text { Assistant } \\
\text { professor }\end{array}$} & Professor & .054 & .087 & .942 & -.19 & .30 \\
\hline & $\begin{array}{l}\text { Associate } \\
\text { professor }\end{array}$ & $.305\left(^{*}\right)$ & .082 & $.004^{*}$ & .07 & .54 \\
\hline & lecturer & -.034 & .100 & .990 & -.32 & .25 \\
\hline \multirow[t]{3}{*}{ lecturer } & Professor & .088 & .107 & .879 & -.21 & .39 \\
\hline & $\begin{array}{l}\text { Associate } \\
\text { professor }\end{array}$ & $.339(*)$ & .103 & $.014^{*}$ & .05 & .63 \\
\hline & $\begin{array}{l}\text { Assistant } \\
\text { professor }\end{array}$ & .034 & .100 & .990 & -.25 & .32 \\
\hline
\end{tabular}

* The mean difference is significant at the .05 level.

Table 10 (test Scheffe) indicates that there are statistical differences in the sample members perspectives according to the academic rank variable between those with the rank of 
associate professor and those with the rank of assistant professor in favour of those with the rank of assistant professor as indicated by the table of arithmetic averages No. 8. This means that the sample members see that the level of job burnout for the faculty members with the rank of assistant professor is higher than the level of job burnout among faculty members with the rank of associate professor.

The results of Table 10 also showed that there were statistical differences between those with the rank of associate professor and the rank of lecturer in favour of the rank of lecturer, as indicated by the table of arithmetic averages No. 8, which means that the sample members see that the level of job burnout among those with the rank of the lecturer is higher than the level of job burnout at the rank of associate professor.

The level of job burnout for the rank of assistant professor and lecturer is higher than the level of jo burnout for the rank of associate professor because these two ranks occupy the lowest academic ranks in the academic ladder of universities, causing an added burden on the individuals and leading to more exerted efforts than other ranks in the attempt to advance their career and rise to higher ranks and work harder to achieve the requirements and conditions of the university in this regard, compared to those with the rank of an associate professor who reached the permanent service, the thing that gives them a comfortable feeling and allows them to work in an atmosphere characterized by stability, unlike those with the rank of assistant professor and the rank of lecturer, who strive with all their energies to reach the stage of permanent service and get a sense of security and stability.

\section{The Third Hypothesis (H3)}

"There is no statistically significant relationship at significance level ( $\alpha \leq 0.05)$ between the level of e-learning during the pandemic and the level of job burnout among faculty members in public and private universities in Jordan"

To identify the relationship between the level of e-learning in public and private universities and the level of faculty members' sense of job burnout, Pearson's correlation coefficient was calculated between them and between the fields for each of them, as indicated by Table No. 11. 
INTERNATIONAL JOURNAL OF ACADEMIC RESEARCH IN BUSINESS AND SOCIAL SCIENCES

Vol. 11, No. 11, 2021, E-ISSN: 2222-6990 @ 2021 HRMARS

Table 11: Correlations between the level of E-learning and the level of Job burnout and their Areas

\begin{tabular}{|c|c|c|c|c|c|}
\hline Areas & & $\begin{array}{l}\text { Emotional } \\
\text { Exhaustion }\end{array}$ & $\begin{array}{l}\text { Depersonalizatio } \\
\mathrm{n}\end{array}$ & $\begin{array}{l}\text { Personal } \\
\text { Accomplishmen } \\
t\end{array}$ & $\begin{array}{l}\text { Job } \\
\text { burnout } \\
\text { (Total) }\end{array}$ \\
\hline \multirow[t]{3}{*}{ Infrastructure } & $\begin{array}{l}\text { Pearson } \\
\text { Correlation }\end{array}$ & $-.182(* *)$ & $-.318(* *)$ & $-.273(* *)$ & $.281(* *)$ \\
\hline & Sig. (2-tailed) & .000 & .000 & .000 & .000 \\
\hline & $\mathrm{N}$ & 525 & 525 & 525 & 525 \\
\hline \multirow{3}{*}{$\begin{array}{l}\text { The } \\
\text { effectiveness of } \\
\text { the educational } \\
\text { process }\end{array}$} & $\begin{array}{l}\text { Pearson } \\
\text { Correlation }\end{array}$ & $-.272(* *)$ & $-.334(* *)$ & $-.379(* *)$ & $\begin{array}{l}- \\
.365(* *)\end{array}$ \\
\hline & Sig. (2-tailed) & .000 & .000 & .000 & .000 \\
\hline & $\mathrm{N}$ & 525 & 525 & 525 & 525 \\
\hline \multirow{3}{*}{$\begin{array}{l}\text { Student } \\
\text { achievement } \\
\text { assessment }\end{array}$} & $\begin{array}{l}\text { Pearson } \\
\text { Correlation }\end{array}$ & $-.258(* *)$ & $-.325(* *)$ & $-.337(* *)$ & $\begin{array}{l}- \\
.340(* *)\end{array}$ \\
\hline & Sig. (2-tailed) & .000 & .000 & .000 & .000 \\
\hline & $\mathrm{N}$ & 525 & 525 & 525 & 525 \\
\hline \multirow{3}{*}{$\begin{array}{l}\text { The } \\
\text { effectiveness of } \\
\text { e-learning }\end{array}$} & $\begin{array}{l}\text { Pearson } \\
\text { Correlation }\end{array}$ & $-.374(* *)$ & $-.392(* *)$ & $-.422(* *)$ & $.442(* *)$ \\
\hline & Sig. (2-tailed) & .000 & .000 & .000 & .000 \\
\hline & $\mathrm{N}$ & 525 & 525 & 525 & 525 \\
\hline \multirow[t]{3}{*}{$\begin{array}{l}\text { E-learning } \\
\text { (Total) }\end{array}$} & $\begin{array}{l}\text { Pearson } \\
\text { Correlation }\end{array}$ & $-.319(* *)$ & $-.400(* *)$ & $-.412(* *)$ & $.417(* *)$ \\
\hline & Sig. (2-tailed) & .000 & .000 & .000 & .000 \\
\hline & $\mathrm{N}$ & 525 & 525 & 525 & 525 \\
\hline
\end{tabular}

** Correlation is significant at the 0.01 level (2-tailed).

Looking at Table 11, it appears that there is a negative correlation with statistical significance at the level of significance ( $\alpha \leq 0.01$ ) between the two main variables, the level of e-learning on the one hand, and the level of job burnout among faculty members on the other. It also appears from the same table that there is a negative correlation between all fields of elearning and all fields of job burnout.

The negative correlation between the level of e-learning and the level of job burnout means that the higher the level of e-learning, the lower the level of job burnout. The results in Table 4 showed that the level of e-learning was moderate, and the results in Table 5 showed that the level of job burnout was also moderate, but despite that, it was found that there is a negative correlation between them meaning that if the level of e-learning is high, the level of job burnout may fall to a low level.

This negative relationship between the two variables, which was also at a moderate level (.417) (Zikmund, 2000), and is statistically significant, means that the link between the variables is real and not the result of chance. This has a strong indication that e-learning is one of the factors causing job burnout among faculty members. This may be because the experience of e-learning is a new experience, as its use was previously very limited, and it 
appeared suddenly, forcing faculty members to prepare themselves to deal with it quickly, which caused various types of psychological and physical pressures, in order to keep up and not waste time. Also, the skills of some of the faculty members in dealing with e-learning were not at the required level, forcing them to make more effort and train in a short time to master the process of dealing with educational platforms, how to upload materials, prepare assignments, and exams...etc. In addition to the problems that many faced during lectures and exams, which require solutions that may sometimes be immediate. There is no doubt that all these factors have caused many to feel tired, dissatisfied with personal accomplishments, and at other times feeling indifferent and give in. Hence, the negative correlation between the two variables may be a logical and natural result, and it needs contemplation by the administrations of public and private universities in Jordan and by the faculty members themselves to improve the reality and raise it to the desired level.

Table 11 showed that there was a statistically significant negative correlation between all fields for both variables, and the highest was for the correlation between the fields of "elearning effectiveness" and "personal accomplishments", which was moderate (-.422). This result is very logical since the more effective the e-learning, the lower the individual's feeling that his accomplishments are insufficient and that he is not satisfied with them. The more effective the e-learning, the more the faculty member feels that he can deal with students' problems better, he feels more active, wants to achieve better, works to create an environment that is suitable for him to accomplish his work, and deals with others calmly. All of this will lead the faculty member to strive towards achieving his goals and ambitions more. The lowest negative correlation between fields was between the fields of "infrastructure" and "emotional exhaustion" which was at a low level (-.182). Perhaps this result is because the infrastructure in the public and private universities are very good as indicated by the sample members when they answered the first question, where the level of their estimates for the field of infrastructure was high. That is, the provision of educational platforms, Internet networks, and technical support related to the e-learning process is very appropriate. Therefore, the link between infrastructure and the field of emotional exhaustion, despite its presence, is a low negative correlation, meaning the more the infrastructure improves in universities, the lower the faculty members feel like they exhausted their energies, tension, emotional exhaustion, and lack of confidence in their professional career and its continuity. The above results indicate, beyond any doubt, that e-learning is one of the factors that may affect job burnout among faculty members in public and private universities in Jordan.

\section{Recommendation}

Based on the findings of this study, the researchers recommend the following:

First: Both public and private universities should pay more attention to e-learning as the results showed that the level of e-learning was moderate. This can be achieved through universities working on:

- Encouraging teachers and students to improve the process of communication between them in various possible ways

- Controlling the examination mechanism and the quality of questions to give a true image of the level of students

- Considering the conditions of teachers and students and assisting them in solving problems that hinder the success of e-learning

Training teachers to deal with e-learning with high efficiency 
Second: Both public and private universities should pay more attention to their faculty members because the results showed that their level of job burnout was moderate. This can be achieved through universities working on:

- $\quad$ Providing a comfortable academic and social work environment

- $\quad$ Paying attention to the personal issues of faculty members, focusing on their achievements, and supporting the distinguished among them

- $\quad$ Allowing them to express their opinion and share ideas

- $\quad$ Dealing with faculty members fairly and equitably

\section{Conclusions}

The study aimed to conduct field research on the level of e-learning in Jordanian public and private universities and the level of job burnout among faculty members in these universities. It also aimed to reveal whether the level of e-learning has a statistically significant relationship with the level of job burnout among faculty members. Two questions and three hypotheses were dealt with which focused on the relationship between the level of e-learning in public and private universities with the job burnout levels among faculty members in these universities. The data in this study was collected from the research sample which was distributed to all public and private universities using the questionnaire tool to measure all the variables that the study dealt with.

The study reached several results; the most important is that the level of e-learning in public and private universities and the job burnout level among faculty members was moderate. It is also clear from the results and the Pearson correlation coefficient that there is a statistically significant relationship between the level of e-learning and job burnout among faculty members in public and private universities. The perspective of the sample members and the results show that the level of e-learning in private universities is slightly higher than in public universities.

Therefore, if universities want to upgrade and improve the level of e-learning, they should pay attention to providing the latest and best educational platforms, large-capacity Internet networks, as well as paying attention to the methods of education, interaction, and communication between teachers and students, which leads to achieving the goals of the educational process and achieving outstanding educational outcomes. To achieve the same goal, universities should also pay attention to the level of job burnout among faculty members, so that they work hard to address all the causes that have to do with it to keep it at a low level.

We conclude from the previous ideas that there is a similarity between public and private universities concerning the subject of this study. Understanding the reality of the problem that this study dealt with may be an indication for future researchers and those who are interested in the same topic, to conduct further studies related to this topic in Jordanian universities. It may also encourage researchers to search topics that are related to the study topic in order to better understand e-learning, its problems, and its obstacles, and to further advance these universities.

\section{References}

Al-hindi and Al-qurashi. (2021). The relationship between job burn-out and the job leakage of male and female administrators- A comparative study between King Abdulaziz University and Jeddah University. Journal of Economic, Administrative and Legal Sciences Volume (5), Issue (12); 30 June 2021 P: 25 - 45. 
Alipio, Mark. (2020) Education During Covid-19 Era: Are Learners in a Less-economically Developed Country Ready for E-Learning? WWW.ECONSTOR.EU

Al-Jaf, M. M. (2020). The effect of job burnout on the job performance of employees, an exploratory study in the Baghdad Distribution Organization - Oil Products Distribution Company. AL-dananeer journal, 1(2),346-378.

Beyouk, M. B. (2015). Career Path Strategy and its Impact on Burnout: Test of the Moderating Role of Organizational Socialization-An Empirical Study on the Jordanian Insurance Companies Master thesis, Faculty of Commerce, Middle East University, Amman Jordan

Chakraborty, P., Mittal, P., Gupta, M. S., Yadav, S., \& Arora, A. (2021). Opinion of students on online education during the COVID-19 pandemic. Human Behavior and Emerging Technologies, 3(3), 357-365.

Dhawan, S. (2020). Online learning: A panacea in the time of COVID-19 crisis. Journal of Educational Technology Systems, 49(1), 5-22.

Dubey, P., \& Pandey, D. (2020). Distance learning in higher education during pandemic: challenges and opportunities. Int. J. Ind. Psychol, 8(2), 43-46.

Fatonia, N. A., Nurkhayatic, E., Nurdiawatid, E., Fidziahe, G. P., Adhag, S., Irawanh, A. P., ... \& Azizik, E. (2020). University students online learning system during Covid-19 pandemic: Advantages, constraints and solutions. Systematic Reviews in Pharmacy, 11(7), 570-576.

Ferraro, F. V., Ambra, F. I., Aruta, L., \& lavarone, M. L. (2020). Distance learning in the covid19 era: Perceptions in Southern Italy. Education Sciences, 10(12), 355.

Gill, R. K. (2017). Burnout related to occupational stress among Library and Information Professionals (LIS). IOSR Journal of Humanities and Social Science, 22(4), 60-65.

Hijazi, H. A., Al-Zoubi, D. M., Al-Gharaibah, S., Alsakarneh, A., \& Al-Hawamdeh, T. (2021). The Impact of Human Resources Management Practices (HRMPs) on Job Burnout among Faculty Members in Public and Private Universities in Jordan. International Journal of Academic Research in Business and Social Sciences, 11(7), 789-813.

Mukhtar, K., Javed, K., Arooj, M., \& Sethi, A. (2020). Advantages, Limitations and Recommendations for online learning during COVID-19 pandemic era. Pakistan journal of medical sciences, 36(COVID19-S4), S27.

Reyes-Chua, E., Sibbaluca, B. G., Miranda, R. D., Palmario, G. B., Moreno, R. P., \& Solon, J. P. T. (2020). The status of the implementation of the e-learning classroom in selected higher education institutions in region IV-A amidst the COVID-19 crisis. Journal of Critical Reviews, 7(11), 253-258.

Sadeghi, M. (2019). A shift from classroom to distance learning: advantages and limitations. International Journal of Research in English Education, 4(1), 80-88.

Sari, T., \& Nayır, F. (2020). Challenges in distance education during the (Covid-19) pandemic period. Qualitative Research in Education, 9(3), 328-360.

Martin, L. (2020). Foundations for Good Practice: The Student Experience of Online Learning in Australian Higher Education during the COVID-19 Pandemic. Australian Government Tertiary Education Quality and Standards Agency.

https://www.voced.edu.au/content/ngv\%3A88893

Sekaran, U., \& Bougie, R. (2019). Research methods for business: A skill building approach. john wiley $\&$ sons.

Simamora, R. M. (2020). The Challenges of online learning during the COVID-19 pandemic: An essay analysis of performing arts education students. Studies in Learning and Teaching, 1(2), 86-103. 
Suryaman, M., Cahyono, Y., Muliansyah, D., Bustani, O., Suryani, P., Fahlevi, M., \& Munthe, A. P. (2020). COVID-19 pandemic and home online learning system: Does it affect the quality of pharmacy school learning. Systematic Reviews in Pharmacy, 11(8), 524-530.

Yang, X., Zhang, B., Wang, L., Cao, L., \& Tong, R. (2021). Exploring the relationships between safety compliance, safety participation and safety outcomes: considering the moderating role of job burnout. International journal of environmental research and public health, 18(8), 4223.

Zikmund, W. G. (2000). Business research methods (6 $6^{\text {th }}$ ed.), Fort Worth: Harcourt College Publishers. 


\section{Appendix 1}

\section{Means/ E-learning scale}

\begin{tabular}{|c|c|c|c|c|c|c|}
\hline NO & Items & $\mathbf{N}$ & $\begin{array}{l}\text { Minimu } \\
\text { m }\end{array}$ & $\begin{array}{l}\text { Maximu } \\
\mathrm{m}\end{array}$ & Mean & $\begin{array}{l}\text { Std. } \\
\text { Deviatio } \\
\text { n }\end{array}$ \\
\hline & Infrastructure field & 525 & 1.00 & 5.00 & 3.68 & .71 \\
\hline 1. & $\begin{array}{l}\text { The e-learning platform is characterized by the } \\
\text { ease of my access to it }\end{array}$ & 525 & 1 & 5 & 4.28 & .812 \\
\hline 2. & $\begin{array}{l}\text { The e-learning platform is characterized by the } \\
\text { ease of students' access to it }\end{array}$ & 525 & 1 & 5 & 3.93 & .880 \\
\hline 3. & The e-learning platform is easy to use & 525 & 1 & 5 & 4.05 & .799 \\
\hline 4. & $\begin{array}{l}\text { The e-learning platform is characterized by the } \\
\text { ability to use illustrations }\end{array}$ & 525 & 1 & 5 & 3.50 & 1.048 \\
\hline 5. & $\begin{array}{l}\text { The educational material is exchanged between } \\
\text { me and the students on the platform easily }\end{array}$ & 525 & 1 & 5 & 3.79 & .873 \\
\hline 6. & $\begin{array}{l}\text { The platform allows the teacher to upload } \\
\text { educational material easily and smoothly }\end{array}$ & 525 & 1 & 5 & 3.98 & .885 \\
\hline 7. & $\begin{array}{l}\text { The platform allows students to download the } \\
\text { assignments required of them easily and } \\
\text { smoothly }\end{array}$ & 525 & 1 & 5 & 3.85 & .966 \\
\hline 8. & $\begin{array}{l}\text { The platform allows students to submit their } \\
\text { exams easily }\end{array}$ & 525 & 1 & 5 & 3.82 & .975 \\
\hline 9. & $\begin{array}{l}\text { The speed of the internet helps me to do my work } \\
\text { easily }\end{array}$ & 525 & 1 & 5 & 3.54 & 1.105 \\
\hline 10. & $\begin{array}{l}\text { I don't have a power outage problem while doing } \\
\text { my work }\end{array}$ & 525 & 1 & 5 & 3.66 & 1.084 \\
\hline 11. & $\begin{array}{l}\text { The university provides appropriate training for } \\
\text { teachers on the use of the e-learning platform }\end{array}$ & 525 & 1 & 5 & 3.54 & 1.069 \\
\hline 12. & $\begin{array}{l}\text { The university provides appropriate training for } \\
\text { students to use the e-learning platform }\end{array}$ & 525 & 1 & 5 & 3.15 & 1.123 \\
\hline 13. & $\begin{array}{l}\text { The university provides the appropriate } \\
\text { technology that helps me prepare the material in } \\
\text { an appropriate manner }\end{array}$ & 525 & 1 & 5 & 3.19 & 1.134 \\
\hline 14. & $\begin{array}{l}\text { The university provides the appropriate technical } \\
\text { support in the event of a platform failure }\end{array}$ & 525 & 1 & 5 & 3.51 & 1.091 \\
\hline \multirow[t]{2}{*}{15.} & $\begin{array}{l}\text { The university is making amendments to the } \\
\text { university's systems and infrastructure to suit the } \\
\text { method of e-learning }\end{array}$ & 525 & 1 & 5 & 3.49 & 1.075 \\
\hline & Effectiveness of the educational process field & 525 & 1.08 & 4.85 & 2.65 & .79 \\
\hline 16. & $\begin{array}{l}\text { E-learning allows me to communicate directly } \\
\text { with students }\end{array}$ & 525 & 1 & 5 & 3.47 & 1.069 \\
\hline 17. & $\begin{array}{l}\text { E-learning allows me to follow up with students } \\
\text { during lecture }\end{array}$ & 525 & 1 & 5 & 3.07 & 1.084 \\
\hline 18. & E-learning allows me to answer students' inquiries & 525 & 1 & 5 & 3.82 & .850 \\
\hline
\end{tabular}


INTERNATIONAL JOURNAL OF ACADEMIC RESEARCH IN BUSINESS AND SOCIAL SCIENCES

Vol. 11, No. 11, 2021, E-ISSN: 2222-6990 @ 2021 HRMARS

\begin{tabular}{|c|c|c|c|c|c|c|}
\hline 19. & $\begin{array}{l}\text { Interaction with students through e-learning is } \\
\text { more than when in person }\end{array}$ & 525 & 1 & 5 & 2.10 & 1.192 \\
\hline 20. & $\begin{array}{l}\text { E-learning gives students the freedom to ask } \\
\text { questions and express opinions }\end{array}$ & 525 & 1 & 5 & 3.12 & 1.055 \\
\hline 21. & $\begin{array}{l}\text { The level of students' motivation towards e- } \\
\text { learning is high }\end{array}$ & 525 & 1 & 5 & 2.50 & 1.162 \\
\hline 22. & $\begin{array}{l}\text { The level of teachers' motivation towards e- } \\
\text { learning is high }\end{array}$ & 525 & 1 & 5 & 2.69 & 1.080 \\
\hline 23. & $\begin{array}{l}\text { The level of students' interaction with the teacher } \\
\text { during e-learning is high }\end{array}$ & 525 & 1 & 5 & 2.50 & 1.042 \\
\hline 24. & $\begin{array}{l}\text { Students focus more during e-learning sessions } \\
\text { than during face-to-face learning }\end{array}$ & 525 & 1 & 5 & 2.02 & .978 \\
\hline 25. & $\begin{array}{l}\text { I can offer practical exercises to students during } \\
\text { the remote lectures }\end{array}$ & 525 & 1 & 5 & 2.93 & 1.081 \\
\hline 26. & $\begin{array}{l}\text { Students' home conditions do not affect the level } \\
\text { of their interaction with the teacher during } \\
\text { remote lectures }\end{array}$ & 525 & 1 & 5 & 2.14 & 1.006 \\
\hline 27. & $\begin{array}{l}\text { Students' ability to understand remote lectures is } \\
\text { better than face-to-face teaching }\end{array}$ & 525 & 1 & 5 & 1.98 & .945 \\
\hline \multirow[t]{2}{*}{28.} & $\begin{array}{l}\text { Students' interest in lessons has increased due to } \\
\text { e-learning }\end{array}$ & 525 & 1 & 5 & 2.09 & 1.055 \\
\hline & Student achievement assessment field & 525 & 1.00 & 5.00 & 2.40 & .83 \\
\hline 29. & $\begin{array}{l}\text { Providing remote tests is an appropriate way to } \\
\text { assess students' achievement }\end{array}$ & 525 & 1 & 5 & 2.09 & 1.080 \\
\hline 30. & $\begin{array}{l}\text { The process of evaluating student achievement } \\
\text { remotely is highly credible }\end{array}$ & 525 & 1 & 5 & 1.97 & 1.018 \\
\hline 31. & $\begin{array}{l}\text { E-learning allows me to assess student } \\
\text { achievement using multiple methods }\end{array}$ & 525 & 1 & 5 & 2.79 & 1.024 \\
\hline 32. & $\begin{array}{l}\text { E-learning allows me to continuously assess } \\
\text { student achievement }\end{array}$ & 525 & 1 & 5 & 2.73 & 1.067 \\
\hline 33. & $\begin{array}{l}\text { The level of student achievement through e- } \\
\text { learning is higher than face-to-face learning }\end{array}$ & 525 & 1 & 5 & 2.82 & 1.424 \\
\hline 34. & $\begin{array}{l}\text { The result of students' achievement through e- } \\
\text { learning reflects the true level of their abilities } \\
\text { and potentials }\end{array}$ & 525 & 1 & 5 & 1.95 & 1.031 \\
\hline 35. & $\begin{array}{l}\text { It is easy for the teacher to assess students' } \\
\text { achievement in e-learning }\end{array}$ & 525 & 1 & 5 & 2.57 & 1.135 \\
\hline \multirow[t]{2}{*}{36.} & $\begin{array}{l}\text { It is easy for the teacher to assess the degree of } \\
\text { understanding and comprehension of the student } \\
\text { from a distance }\end{array}$ & 525 & 1 & 5 & 2.31 & 1.036 \\
\hline & E-learning effectiveness field & 525 & 1.00 & 4.79 & 2.39 & .85 \\
\hline 37. & $\begin{array}{l}\text { E-learning allows me to invest my time in a better } \\
\text { way than it would if the learning was face to face }\end{array}$ & 525 & 1 & 5 & 2.65 & 1.247 \\
\hline 38. & $\begin{array}{l}\text { E-learning allows me to make better use of lecture } \\
\text { time than it would if it was face-to-face }\end{array}$ & 525 & 1 & 5 & 2.63 & 1.217 \\
\hline
\end{tabular}




\begin{tabular}{|l|l|l|l|l|l|l|}
\hline 39. & $\begin{array}{l}\text { I feel that students are achieving the desired } \\
\text { benefit through the e-learning process }\end{array}$ & 525 & 1 & 5 & 2.37 & 1.104 \\
\hline 40. & $\begin{array}{l}\text { The energy to prepare and present the material in } \\
\text { e-learning is less than if the learning was in person }\end{array}$ & 525 & 1 & 5 & 2.13 & 1.117 \\
\hline 41. & $\begin{array}{l}\text { The efforts I make during the e-learning process } \\
\text { do not negatively affect my social relationships }\end{array}$ & 525 & 1 & 5 & 2.62 & 1.125 \\
\hline 42. & $\begin{array}{l}\text { My efforts during the e-learning process do not } \\
\text { negatively affect my family relationships }\end{array}$ & 525 & 1 & 5 & 2.79 & 1.149 \\
\hline 43. & $\begin{array}{l}\text { The e-learning method is better than the face-to- } \\
\text { face method }\end{array}$ & 525 & 1 & 5 & 1.79 & 1.007 \\
\hline 44. & $\begin{array}{l}\text { E-learning helps me get my work done faster than } \\
\text { face-to-face learning }\end{array}$ & 525 & 1 & 5 & 2.51 & 1.106 \\
\hline 45. & $\begin{array}{l}\text { I feel that my performance in e-learning is better } \\
\text { than traditional learning }\end{array}$ & 525 & 1 & 5 & 2.29 & 1.076 \\
\hline 46. & $\begin{array}{l}\text { I feel that e-learning has strengthened my } \\
\text { relationship with students }\end{array}$ & 525 & 1 & 5 & 2.11 & 1.104 \\
\hline 47. & I enjoy the e-learning experience & 525 & 1 & 5 & 2.64 & 1.168 \\
\hline 48. & $\begin{array}{l}\text { I feel that it is easy for students to acquire the } \\
\text { necessary skills and knowledge through e- } \\
\text { learning }\end{array}$ & 525 & 1 & 5 & 2.46 & 1.126 \\
\hline 49. & I feel satisfied with the e-learning process & 525 & 1 & 5 & 2.58 & 1.164 \\
\hline 50. & $\begin{array}{l}\text { I think that e-learning is better than face-to-face } \\
\text { education in general }\end{array}$ & 525 & 1 & 5 & 1.89 & 1.003 \\
\hline & E-learning (Total) & 525 & 1.06 & 4.72 & 2.85 & .68 \\
\hline
\end{tabular}




\section{Appendix 2}

Means/ Job burnout scale

\begin{tabular}{|c|c|c|c|c|c|c|}
\hline $\mathbf{N}$ & Items & $\mathbf{N}$ & $\begin{array}{l}\text { Minimu } \\
\text { m }\end{array}$ & $\begin{array}{l}\text { Maximu } \\
\text { m }\end{array}$ & Mean & $\begin{array}{l}\text { Std. } \\
\text { Deviatio } \\
\text { n }\end{array}$ \\
\hline & Emotional exhaustion field & 525 & 1.00 & 4.86 & 3.11 & .88 \\
\hline 1. & I feel emotionally drained from the work I do & 525 & 1 & 5 & 3.22 & 1.026 \\
\hline 2. & I feel exhausted at the end of the day & 525 & 1 & 5 & 3.50 & 1.117 \\
\hline 3. & $\begin{array}{l}\text { I feel tired when I get up in the morning to start } \\
\text { my work }\end{array}$ & 525 & 1 & 5 & 3.04 & 1.154 \\
\hline 4. & $\begin{array}{l}\text { I feel nervous because of dealing with students } \\
\text { and colleagues all day long }\end{array}$ & 525 & 1 & 5 & 2.88 & 1.113 \\
\hline 5. & I feel bored and annoyed because of my work & 525 & 1 & 5 & 3.27 & 1.235 \\
\hline 6. & I feel like I'm exhausting all my effort in my work & 525 & 1 & 5 & 3.39 & 1.137 \\
\hline \multirow[t]{2}{*}{7.} & I feel like the end of my career is near & 525 & 1 & 5 & 2.44 & 1.199 \\
\hline & Depersonalization field & 525 & 1.00 & 5.00 & 2.54 & .90 \\
\hline 8. & $\begin{array}{l}\text { I feel that I treat some people in my work as if they } \\
\text { are lifeless }\end{array}$ & 525 & 1 & 5 & 2.94 & 1.253 \\
\hline 9. & $\begin{array}{l}\text { I've been tough on people in general since I } \\
\text { started this kind of work }\end{array}$ & 525 & 1 & 5 & 2.41 & 1.055 \\
\hline 10. & $\begin{array}{l}\text { I feel anxious because of the cruelty and dullness } \\
\text { that my work is causing me }\end{array}$ & 525 & 1 & 5 & 2.65 & 1.162 \\
\hline 11. & $\begin{array}{l}\text { I feel indifferent about what happens to others in } \\
\text { the work environment }\end{array}$ & 525 & 1 & 5 & 2.43 & 1.067 \\
\hline \multirow[t]{2}{*}{12} & $\begin{array}{l}\text { I feel like my students and colleagues are blaming } \\
\text { me for the problems they are facing }\end{array}$ & 525 & 1 & 5 & 2.25 & .989 \\
\hline & Personal Accomplishment field & 525 & 1.00 & 5.00 & 2.82 & .76 \\
\hline 13. & $\begin{array}{l}\text { I can't understand how people feel about my } \\
\text { profession }\end{array}$ & 525 & 1 & 5 & 2.65 & 1.037 \\
\hline 14. & $\begin{array}{l}\text { I deal with the problems of students and } \\
\text { colleagues in low efficiency }\end{array}$ & 525 & 1 & 5 & 2.39 & 1.042 \\
\hline 15. & $\begin{array}{l}\text { I do not feel that I negatively affect the lives of } \\
\text { others through my work }\end{array}$ & 525 & 1 & 5 & 3.20 & 1.065 \\
\hline 16. & I don't feel energetic in my work & 525 & 1 & 5 & 3.15 & 1.192 \\
\hline 17. & $\begin{array}{l}\text { I can't create the right atmosphere to do my work } \\
\text { effectively }\end{array}$ & 525 & 1 & 5 & 2.83 & 1.133 \\
\hline 18. & $\begin{array}{l}\text { I do not feel comfortable and happy in my work } \\
\text { and when dealing with students and colleagues }\end{array}$ & 525 & 1 & 5 & 3.21 & 1.129 \\
\hline 19. & $\begin{array}{l}\text { I get nervous when dealing with psychological } \\
\text { problems }\end{array}$ & 525 & 1 & 5 & 2.59 & 1.128 \\
\hline \multirow[t]{2}{*}{20.} & $\begin{array}{l}\text { I don't feel that I have achieved worthy things } \\
\text { while working at the university }\end{array}$ & 525 & 1 & 5 & 2.56 & 1.185 \\
\hline & Job Burnout (Total) & 525 & 1.00 & 4.95 & 2.85 & .75 \\
\hline
\end{tabular}

